\title{
Influence of nutrition on the effectiveness of superovulation programmes in ewes: effect on oocyte quality and post-fertilization development
}

\author{
J. M. Lozano ${ }^{*}$, P. Lonergan ${ }^{2,3}$, M. P. Boland ${ }^{2,3}$ and D. O'Callaghan ${ }^{1,3}$ \\ ${ }^{1}$ Faculty of Veterinary Medicine and ${ }^{2}$ Agriculture; and ${ }^{3}$ Conway Institute for Biomolecular \\ and Biomedical Research, University College Dublin, Dublin, Ireland
}

Two experiments were carried out to study the effect of nutrition on embryo development in two periods in superovulated ewes (Expt 1) and on oocyte developmental capacity during the late follicular phase (Expt 2). In Expt 1, a lower superovulation response in terms of animals ovulating $(P<0.05)$, ovulation rate per ewe ovulating $(P=0.1)$ and number of good quality embryos per animal treated $(P<0.07)$ was noted in ewes fed an ad libitum diet compared with ewes offered control (1.5 times the daily maintenance energy requirements, $1.5 \times M)$ or low energy $(0.5 \times \mathrm{M})$ diets. Nutrition also modified the morphological and functional quality of the oocytes and embryos recovered. Thus, $92 \%$ of day 4 embryos recovered from ewes offered the control diet were classified as good embryos, compared with 70 and $82 \%$ of those recovered from ewes offered the ad libitum and low diets, respectively $(P<0.05)$. Ewes offered the ad libitum diet had a greater percentage of poorly developed embryos compared with ewes offered the control or low diets $(P<0.05)$. Ewes fed the low diet tended to have more non-fertilized oocytes than ewes offered the control diet $(P=0.09)$. Diet of recipient ewes to which good quality embryos were transferred on day 4 did not affect embryo quality, when assessed 12 days later (day 16 of pregnancy).
However, recipient diet affected prostaglandin $F_{2 \alpha}\left(\mathrm{PGF}_{2 \alpha}\right)$ production in vitro, and uterine tissue that originated from recipient ewes on the low diet secreted more PGF $_{2 \alpha}$ relative to uterine tissue that originated from recipients on the control diet $(P<0.05)$. In Expt 2, fewer total $(P<0.05)$ and good quality $(P<0.01)$ oocytes and a lower percentage of good quality oocytes $(P<0.01)$ were obtained from superovulated ewes offered the ad libitum diet compared with ewes offered the low diet. In addition, cleavage rate tended to be higher ( 51 versus $35 \%, P=0.09$ ) in ewes offered the low diet compared with ewes offered the ad libitum diet. In conclusion, changes in diet can affect the quality of the oocyte and embryo in superovulated sheep. A lower superovulation response and a decrease in the quality of oocytes and embryos indicate that ad libitum diets are highly detrimental for superovulatory programmes when compared with low and control diets. In addition, the results from the present study indicate that a low energy diet during early embryo development increased the uterine production in vitro of $\mathrm{PGF}_{2 \alpha}$ which could lead to a poor uterine environment thereby compromising the development of the embryo.

\section{Introduction}

Extremes of nutrition can increase embryo mortality or delay embryo development in ewes. Undernutrition has been shown to delay embryo development during the first 2 weeks after fertilization (Parr et al., 1987; Abecia et al., 1997) and increase embryo mortality in the first 2 weeks of pregnancy (Rhind et al., 1989; Abecia et al.,

*Current address: Department of Veterinary Preclinical Studies, University of Glasgow Veterinary School, Bearsden Road, Glasgow G61 1QH, UK

Email: j.m.lozano@vet.gla.ac.uk
1995). Conversely, overfeeding can also lead to reduced pregnancy rates (Parr et al., 1987) and a decrease in the rate of development in vitro and the viability of embryos collected on day 2 after fertilization (Creed et al., 1994). However, it is not known whether the effects of diet on embryo development are solely confined to the period of embryo development or whether diet can also affect oocyte development before fertilization, which is subsequently manifested in poor embryo development.

Progesterone is the main hormone involved in the maintenance of pregnancy. At present, the relationship between the effect of nutrition on jugular blood 
concentrations of progesterone and embryo mortality is not clear. It has been shown that there is an inverse relationship between peripheral progesterone concentrations and nutrition (Parr et al., 1987; Rhind et al., 1989; Creed et al., 1994). This relationship is most likely a consequence of an increased catabolism of steroids by the larger livers often present in ewes fed a high energy diet (Parr et al., 1993).

Although this finding may explain the increase in embryo mortality in ewes fed a high energy diet, embryo mortality can be increased in both underfed and overfed ewes. Local concentrations of progesterone, measured at the ovary and uterus, are not related to peripheral concentrations measured in jugular venous blood (Lozano et al., 1998). However, concentrations of progesterone in circulation near the reproductive organs may be biologically more important for embryo survival. As such, it is of interest that Lozano et al. (1998) reported lower endometrial progesterone concentrations on day 5 of the luteal phase in ewes offered half maintenance energy requirements compared with ewes offered 1.5 times maintenance energy requirements. These concentrations were inverse to those found in plasma collected from the jugular vein (Lozano et al., 1998).

The main hormone responsible for luteolysis is prostaglandin $\mathrm{F}_{2 \alpha}\left(\mathrm{PGF}_{2 \alpha}\right)$, although interferon tau (IFN- $\tau$ ) is the main embryonic antiluteolytic signal in ruminants. IFN- $\tau$ suppresses transcription of the oestrogen receptor and oxytocin receptor genes in the ovine endometrium (Spencer and Bazer, 1996), which may transform the response to circulating oxytocin from stimulating $\mathrm{PGF}_{2 \alpha}$ to prostaglandin E (PGE) (Asselin et al., 1997) and, thus, regulate luteolysis. IFN- $\tau$ is secreted by the trophectoderm of sheep conceptuses between day 11 and day 20 of pregnancy with maximal production per cell on about day 15 in sheep (for a review, see Martal et al., 1998). Therefore, this is a critical period for embryo survival. Changes in embryo quality that could affect IFN- $\tau$ secretion during this period could adversely affect pregnancy rate.

The objective of the present study was to investigate the effect of nutrition on oocyte and embryo quality near the time of fertilization and to examine the role of progesterone, insulin-like growth factor I (IGF-I) and insulin in mediating the effects of nutrition on embryo quality. The hypothesis tested was that overnourished and undernourished ewes would have decreased concentrations of IGF-I and insulin and endometrial content of progesterone, and they would produce lower quality embryos after superovulation than would ewes in a control plane of nutrition. In the first experiment, an effect of nutrition was observed as early as day 4 of pregnancy, and a second experiment was carried out to test the hypothesis that overnutrition results in a decrease in the quality of oocytes when compared with undernutrition.

\section{Materials and Methods}

\section{Experiment 1}

The experimental design for Expt 1 is summarized (Fig. 1).

Animals and treatments. Forty-four crossbred adult ewes were used as embryo donors and were maintained in individual pens with free access to water. After 5 days of adaptation to the pens and grass meal as their dietary source, animals were allocated randomly to one of three groups and offered a diet of grass meal $(90 \%$ dry matter (DM), $10.75 \mathrm{MJ}$ metabolizable energy $\mathrm{kg}^{-1}$ DM, $16 \%$ crude protein in DM) calculated to provide 0.5 times the maintenance energy requirements $(0.5 \times M$; low group, $n=22), 1.5$ times the maintenance energy requirements $(1.5 \times M$; control group, $n=11)$ or an ad libitum diet (ad libitum group, $n=11$, intake estimated by residues $=2.2$ times the maintenance energy requirements). At the same time, 80 ewes were used as embryo recipients and allocated to diets of grass meal at $0.5 \times M$ (low recipient group, $n=20$ ) or $1.5 \times M$ (control recipient group, $n=60$ ). Control recipient ewes were maintained in communal pens with free access to mineral blocks, whereas low recipient ewes were maintained in individual pens. All the donors and the low recipient ewes received $20 \mathrm{~g} \mathrm{day}^{-1}$ of a general purpose sheep mineral supplement (GP Sheep Mineral, C. Wynne Co. Ltd, Ireland; Vitamin A, Vitamin D3, $\alpha$-tocopherol, $\mathrm{Co}, \mathrm{Mn}, \mathrm{I}, \mathrm{Se}, \mathrm{Ca}, \mathrm{Na}, \mathrm{Mg}$ ).

All ewes were synchronized using a $60 \mathrm{mg}$ medroxy progesterone acetate pessary (Veramix Sheep, Pharmica and Upjohn Ltd, Dublin) inserted 5 days after the start of dietary treatment and withdrawn 2 weeks later. Donor ewes were superovulated with $200 \mathrm{mg} \mathrm{NIH}-$ FSH-equivalent (Folltropin-V, Vetrepharm Inc., Ontario). This treatment was administered i.m. in six injections of equal dose starting $48 \mathrm{~h}$ before pessary withdrawal (day 0), with the final injection administered $12 \mathrm{~h}$ after pessary withdrawal. Rams were introduced $36 \mathrm{~h}$ after pessary withdrawal and onset of oestrus was examined at $8 \mathrm{~h}$ intervals. Pessary withdrawal was delayed for $12 \mathrm{~h}$ in donor ewes relative to recipient ewes. Recipient ewes received an injection of 500 iu equine chorionic gonadotrophin (eCG) (Folligon ${ }^{\circledR}$, Intervet, Boxmeer) at the time of pessary withdrawal.

Weight and body condition score (BCS) were recorded on a weekly basis. Blood samples were collected twice each week in donor ewes by jugular venepuncture from the day before the nutritional treatment started until the end of the experiment. IGF-I and insulin were assayed in these samples to monitor the metabolic state of the ewes. IGF-I concentration is known to increase during oestrus (Spicer and Zavy, 1992); therefore, additional samples were collected each day from day 3 to the day of slaughter and assayed for insulin and IGF-I. These samples were also assayed for progesterone to determine 


\begin{tabular}{|c|}
\hline Donor ewes (low) \\
\hline Recipient ewes (low) \\
\hline
\end{tabular}

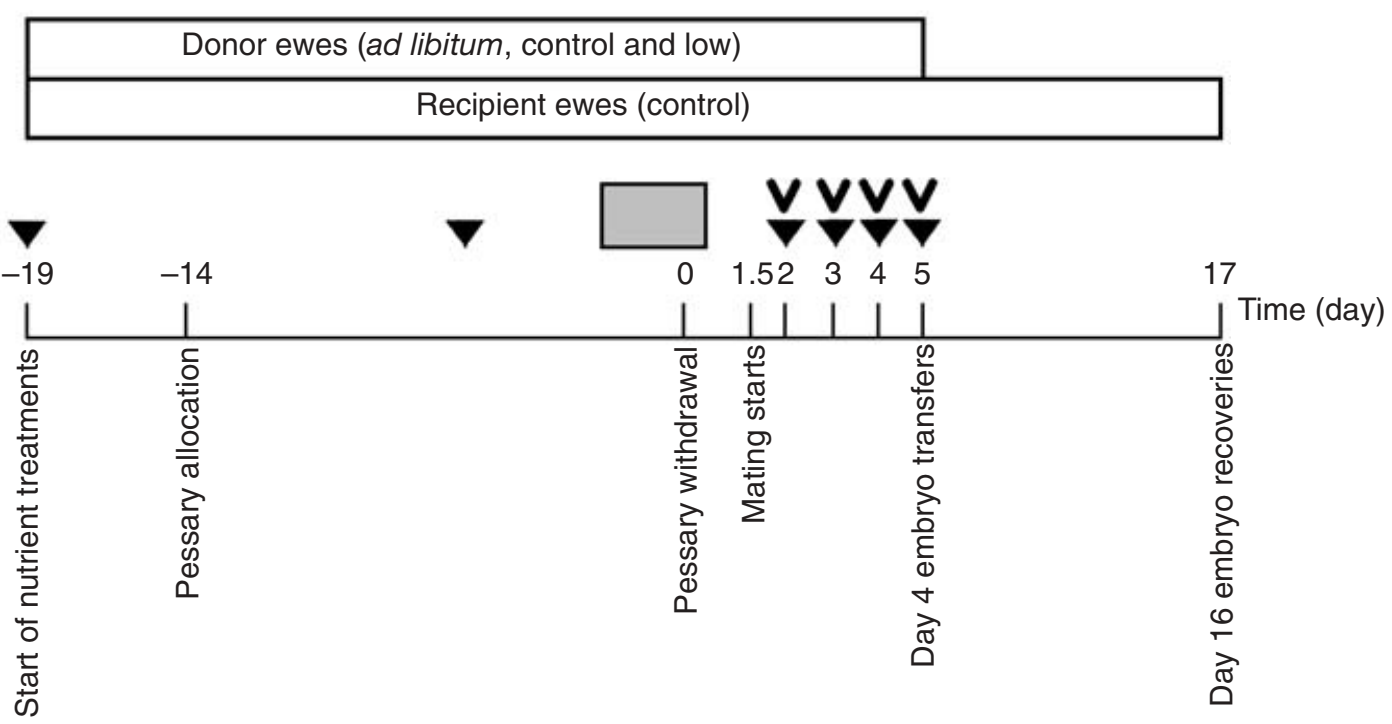

Fig. 1. Design of Expt 1. After synchronization and superovulation treatment (FSH treatment, shaded bar) day 4 embryos were recovered, classified and transferred to synchronized embryo recipients. After a further 12 days, day 16 embryos were recovered from recipients and embryo production of interferon- $\tau$ in vitro was analysed. Insulin-like growth factor I (closed arrowheads) and progesterone (open arrowheads) concentrations were measured in embryo donor ewes. Low diet: diet of grass meal (90\% dry matter (DM), 10.75 MJ metabolizable energy $\mathrm{kg}^{-1} \mathrm{DM}, 16 \%$ crude protein in DM) calculated to provide 0.5 times the maintenance energy requirements; control diet: 1.5 times the maintenance energy requirements; ad libitum diet: intake estimated by residues $=2.2$ times the maintenance energy requirements.

the increase in progesterone concentration during the luteal phase. Progesterone concentration was also a measure of ovulation in some ewes fed the low diet that did not undergo surgery.

On day 5 after pessary withdrawal, donor ewes fed the ad libitum or control diets that showed oestrous behaviour (seven and nine ewes, respectively) and 15 donor ewes fed the low diet were anaesthesized (Saggatal $\mathbb{R}$, Merial Animal Health Ltd, Lyon) and, after laparotomy, blood samples were collected from the ovarian vein. Subsequently, all the ewes were killed with an overdose of sodium pentobarbitone (Euthatal, Rhône Mérieux, Hertfordshire). The uterus was removed and oviducts were flushed with PBS to collect the embryos. Uterine samples were frozen in dry ice and subsequently stored at $-70^{\circ} \mathrm{C}$ until progesterone content was determined. The liver was collected immediately and weighed.

Ewes were decapitated immediately after slaughter. Pituitary glands were dissected and samples from the anterior pituitary gland were snap-frozen in liquid nitrogen and stored at $-70^{\circ} \mathrm{C}$ until analysed for $\mathrm{FSH}$ and LH content.

Recovered embryos were classified according to their stage of development. On day 4 of pregnancy, the embryo would normally have progressed to at least the eight-cell stage (Fahey et al., 2001). Therefore, the embryos recovered were classified as: empty zones and one-cell embryos (non-fertilized embryos), up to eightcell embryos (retarded embryos) and embryos of eightcells or more (normal embryos).

Embryos that were collected from donor ewes on the three diets and were considered to be good quality ( $\geqslant$ eight-cells and acceptable morphological characteristics) were transferred to recipient ewes on control diets by surgical laparotomy. Recipient ewes on the low diet received good quality embryos produced in ewes on the low diet only, as a positive control for the effect of nutrition before day 4 of pregnancy.

A maximum of two embryos was transferred to the uterine horn ipsilateral to the most recent ovulation and each ewe received embryos originating from ewes in only one nutritional group. One control and four low recipient ewes received one embryo.

At day 12 after transfer of embryos, all recipient ewes were killed. The uteri were flushed with PBS to recover the embryos and samples of endometrium were then collected.

Incubation of endometrial tissue. Approximately $100 \mathrm{mg}$ pieces of endometrial tissue from recipient ewes 
were washed in TCM-199 and placed into individual wells of a 24-well tissue culture plate containing $500 \mu \mathrm{l}$ of cell culture medium. Samples from each uterine horn were cultured in duplicate with or without oxytocin $\left(1 \mu \mathrm{mol} \mathrm{I}^{-1}\right)$ and incubated for $24 \mathrm{~h}$ in $5 \% \mathrm{CO}_{2}$ in humidified air at $37^{\circ} \mathrm{C}$.

The cell culture medium consisted of Ham's F-12 medium supplemented with antibiotics, L-glutamine $\left(0.29 \mathrm{mg} \mathrm{ml}^{-1}\right)$, insulin $\left(5 \mu \mathrm{g} \mathrm{ml}^{-1}\right)$, transferrin (5 $\mu \mathrm{g}$ $\mathrm{ml}^{-1}$ ) and selenium (5 $\mathrm{ng} \mathrm{ml}^{-1}$ ) (Thibodeaux et al., 1994). There were two replicates for each tissue sample collected. After culture, the medium was collected and stored at $-20^{\circ} \mathrm{C}$ until $\mathrm{PGF}_{2 \alpha}$ and $\mathrm{PGE}_{2}$ concentrations were determined.

In vitro culture of conceptuses. Conceptuses obtained from recipient ewes were transferred into Petri dishes containing $15 \mathrm{ml}$ modified Eagle's minimum essential medium (MEM) supplemented with $2 \%$ penicillin and streptomycin, and incubated for $24 \mathrm{~h}$ in $5 \% \mathrm{CO}_{2}$ in humidified air at $39^{\circ} \mathrm{C}$. After culture, the medium was collected and stored at $-20^{\circ} \mathrm{C}$ until the IFN- $\tau$ concentration was determined.

Endometrial progesterone content. Uterine concentrations of progesterone were determined using the technique described by Lozano et al. (1998). Endometrial tissue samples $(500 \mathrm{mg})$ were homogenized in $10 \mathrm{ml}$ isotonic buffer (102.5 g sucrose $\mathrm{I}^{-1}, 0.375 \mathrm{~g} \mathrm{EDTA} \mathrm{I}^{-1}$,

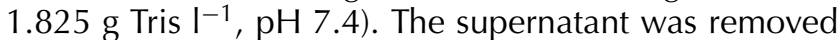
after centrifugation at $1000 \mathrm{~g}$ for $10 \mathrm{~min}$. Progesterone was extracted from the supernatant, using $2 \mathrm{ml}$ petroleum spirit each time. The extraction was repeated four times. The resulting extract was reconstituted in $300 \mu \mathrm{I}$ PBS and assayed for progesterone.

The proportion of progesterone recovered was estimated by measuring the recovery of tritiated progesterone added to a duplicate of the homogenate and the appropiate correction factor was then applied to the measured concentrations (Lozano et al., 1998).

Hormone assays. For the IFN- $\tau$ anti-viral assay, culture medium was analysed for anti-viral activity using a cytophatic effect. The antiviral effect was quantified using Madin-Darby bovine kidney cell line (MDBK), Vesicular Stomatitis Virus Indiana strain as challenge virus and calibrated using GA 23-902-530 reference sample (NIH, Bethesda, MD) as described by La Bonnardière and Laude (1981). Results were expressed in international units (iu) as the reciprocal of the last dilution capable of preventing virus-induced cytophatic effect.

Culture media from wells were analysed for $\mathrm{PGF}_{2 \alpha}$ and $\mathrm{PGE}_{2}$ using $\mathrm{PGF}_{2 \alpha}$ and $\mathrm{PGE}_{2}$ enzymeimmunoassay kits (Cayman Chemical Co., Ann Arbor, MI). The kits were used in accordance with the manufacturer's instructions. Intra- and interassay coefficients of variation for quality control samples were 8.2 and $10.7 \%$ for $\mathrm{PGF}_{2 \alpha}\left(105.8 \pm 3.9 \mathrm{pg} \mathrm{ml}^{-1}\right)$ and 10.8 and $12.4 \%$ for $\mathrm{PGE}_{2}\left(30.0 \pm 1.3 \mathrm{pg} \mathrm{ml}^{-1}\right)$, respectively. The sensitivity of the assay was 7.8 and $3.9 \mathrm{pg} \mathrm{m}^{-1}$ for $\mathrm{PGF}_{2 \alpha}$ and $\mathrm{PGE}_{2}$ respectively.

Serum and endometrial concentrations of progesterone were measured using the AutoDelfiaTM fluoroimmunoassay (Wallac Ltd, Dublin). The kit was used in accordance with the manufacturer's instructions. Mean intra- and interassay coefficients of variation were 23.3 and $24.2 \%$ for low $\left(0.48 \pm 0.05 \mathrm{ng} \mathrm{m}^{-1}\right), 15.0$ and $13.1 \%$ for medium $\left(1.42 \pm 0.09 \mathrm{ng} \mathrm{ml}^{-1}\right)$ and 9.8 and $13.0 \%$ for high $\left(2.24 \pm 0.13 \mathrm{ng} \mathrm{ml}^{-1}\right)$ standards, respectively. The sensitivity of the assay was $0.05 \mathrm{ng} \mathrm{ml}^{-1}$.

Serum IGF-I concentration was measured using a two-site immunoenzymometric assay, the OCTEIA ${ }^{\circledR}$ IGF-I ELISA kit (IDS Ltd, Boldon). Mean intra- and interassay coefficients of variation were 8.6 and $23.7 \%$ for low $\left(0.29 \pm 0.02 \mu \mathrm{g} \mathrm{I}^{-1}\right)$ and 5.2 and $13.8 \%$ for high $\left(0.70 \pm 0.02 \mu \mathrm{g} \mathrm{I}^{-1}\right)$ quality control samples, respectively. The sensitivity of the assay was $1.9 \mu \mathrm{g} \mathrm{ml}^{-1}$.

Serum concentrations of insulin were measured using a fluoroimmunoassay (AutoDELFIA ${ }^{\circledR}$ kit, Wallac Ltd, Turku). Mean intra- and interassay coefficients of variation were 1.4 and $1.9 \%$ for low $(4.63 \pm 0.03$ uiu $\mathrm{ml}^{-1}$ ) and 1.9 and $1.2 \%$ for high (49.20 \pm 0.39 $\mu$ iu $\mathrm{ml}^{-1}$ ) quality control samples, respectively. The sensitivity of the assay was $0.5 \mu \mathrm{iu} \mathrm{ml}^{-1}$.

LH pituitary content was measured by radioimmunoassay (Sweeney et al., 1997). Mean intra- and interassay coefficients of variation were 11.4 and $10.5 \%$ for low $\left(0.44 \pm 0.05 \mathrm{ng} \mathrm{ml}^{-1}\right)$ and 5.5 and $9.9 \%$ for high $\left(6.01 \pm 0.34 \mathrm{ng} \mathrm{ml}^{-1}\right)$ quality control samples, respectively. The sensitivity of the assay was $0.1 \mathrm{ng} \mathrm{ml}-1$.

FSH pituitary content was measured by radioimmunoassay (Crowe et al., 1997). Samples were run in a single assay with mean intra-assay coefficients of variation for low $\left(0.39 \pm 0.02 \mathrm{ng} \mathrm{ml}^{-1}\right)$, medium $(0.84 \pm 0.02 \mathrm{ng}$ $\left.\mathrm{ml}^{-1}\right)$ and high $\left(3.19 \pm 0.05 \mathrm{ng} \mathrm{ml}^{-1}\right)$ quality control samples of $9.2,6.3$ and $4.1 \%$, respectively. The sensitivity of the assay was $0.06 \mathrm{ng} \mathrm{ml}^{-1}$.

\section{Experiment 2}

Animals and treatments. Eighteen crossbred ewes were maintained in individual pens and offered the same grass meal as in Expt 1 . After 5 days of adaptation and 2 days before the start of the same synchronization treatment as in Expt 1, they were divided into two nutritional groups that received either ad libitum $(n=9)$ or $0.5 \times M$ diets (low, $n=9$ ). All ewes were superovulated with 1500 iu eCG administered $48 \mathrm{~h}$ before pessary withdrawal. At pessary withdrawal, all the ewes were killed. The ovaries were recovered and placed in PBS at approximately $35^{\circ} \mathrm{C}$. 
Table 1. Liver mass $(\mathrm{kg})$ in ewes fed an ad libitum diet, or 1.5 (control) or 0.5 (low) times maintenance energy requirements

\begin{tabular}{lccc}
\hline & Ad libitum & Control & Low \\
\hline Number of ewes & 6 & 9 & 15 \\
Liver mass (kg) & $1.28 \pm 0.04^{\mathrm{a}}$ & $1.07 \pm 0.06^{\mathrm{b}}$ & $0.78 \pm 0.02^{\mathrm{c}}$ \\
Liver:body weight ratio & $1.8 \times 10^{-2} \pm 7.0 \times 10^{-4 \mathrm{a}}$ & $1.6 \times 10^{-2} \pm 6.8 \times 10^{-4 \mathrm{~b}}$ & $1.32 \times 10^{-2} \pm 3.7 \times 10^{-4 \mathrm{c}}$ \\
\hline
\end{tabular}

Values are mean $\pm \mathrm{SE}$.

Low diet: diet of grass meal (90\% dry matter (DM), $10.75 \mathrm{MJ}$ metabolizable energy kg-1 DM, $16 \%$ crude protein in DM) calculated to provide 0.5 times the maintenance energy requirements; control diet: 1.5 times the maintenance energy requirements; ad libitum diet: intake estimated by residues $=2.2$ times the maintenance energy requirements.

${ }^{a b c}$ Within the same row, values with different superscripts are significantly different $(P<0.01)$.

Oocytes were aspirated from all follicles that were $>2 \mathrm{~mm}$ in diameter. The oocytes were graded from one to four with regard to the morphology of the cumulus cell layers (Ward et al., 2000): grade 1: oocytes with a compact multilayered cumulus investment; grade 2 : intermediate oocytes; grade 3: denuded oocytes; and grade 4: oocytes had an expanded cumulus. All the oocytes recovered were matured and fertilized in vitro and embryos were cultured as described by Carolan et al. (1995). The number of oocytes cleaved was assessed at $48 \mathrm{~h}$ after insemination and the number of oocytes developing to the blastocyst stage was assessed on days 5, 6 and 7 after insemination.

\section{Statistical analysis}

The main effects of food intake on liveweight, body condition, and serum concentrations of IGF-I and insulin were analysed using ANOVA with repeated measures. Liver mass, IFN- $\tau$ secretion by the conceptus, endometrial secretion of $\mathrm{PGF}_{2 \alpha}$ and $\mathrm{PGE}_{2}$ in vitro, progesterone concentrations in the endometrium, ovarian and jugular veins, and $\mathrm{FSH}$ and $\mathrm{LH}$ pituitary content were compared using ANOVA. Duncan's post-test was performed when necessary in Expt 1. Data that were not normally distributed were logarithmically transformed before statistical analysis. Ovulation rate, classification of the embryos and oocytes recovered, cleavage rate, blastocyst formation rate, stage of development of embryo and embryo survival were compared using chisquared tests.

\section{Results}

\section{Experiment 1}

Weight and body condition. Underfed ewes showed a significant decrease $(P<0.001)$ in body weight, whereas ewes fed the ad libitum diet showed a significant increase $(P<0.001)$ in body weight during the period in which the nutritional treatments were applied. Ewes that received the control diet showed significant changes $(P<0.05)$ in body weight, although initial body weight and weight at the time that the animals were killed were similar $(67.9 \pm 2.3,65.8 \pm 2.2,64.6 \pm 1.8 \mathrm{~kg}$ at the start and $73.5 \pm 2.4,68.9 \pm 6.8,61.5 \pm 1.8 \mathrm{~kg}$ at the end of the experiment for ewes offered the ad libitum, control and low diets, respectively). Ewes fed the ad libitum or control diets maintained their BCS throughout the experiment. However, underfed ewes showed a significant decrease $(P<0.001)$ in BCS during the experiment $(2.59 \pm 0.10,2.48 \pm 0.06,2.49 \pm 0.06$ at the start $2.60 \pm 0.06,2.48 \pm 0.08$, and $2.42 \pm 0.04$ at the end of the experiment for ewes offered the ad libitum, control and low diets, respectively).

There were significant differences in liver mass among all the groups, and ewes had higher liver mass and ratio of liver to body weight at higher food intakes $(P<0.001)$ (Table 1).

Hormone and metabolite concentrations. There was an inverse relationship between level of nutrition and jugular progesterone concentration. Jugular concentrations of progesterone in ewes fed the low and control diets increased significantly from day 2 to day 5 after pessary withdrawal $(P<0.05)$. No significant changes were observed in the ewes fed ad libitum in the same period. Therefore, on day 4 and day 5, jugular blood progesterone concentrations were highest in ewes on the low diet, lowest in ewes on the ad libitum diet and intermediate in ewes on the control diet (Fig. 2a).

Mean serum progesterone concentrations in the ovarian vein ipsilateral to the corpus luteum tended to be higher in ewes offered the low diet and lower in ewes offered the ad libitum diet with intermediate values in the control ewes $(P=0.07)$ (Fig. 2b). Ovarian vein and jugular progesterone concentrations were correlated with the number of corpora lutea recorded at slaughter $(r=0.677 ; P<0.05)$. The endometrial content of progesterone was not different among groups (Fig. 2b).

On day 5 after pessary withdrawal, pituitary LH content was lower in ewes offered the low diet compared with ewes offered the control diet $(4.3 \pm 0.8$ and $2.4 \pm$ $0.3 \mu \mathrm{g} \mathrm{mg}^{-1}$ for ewes offered control and low diets, respectively, $P<0.05)$, but no differences were found between ewes offered the ad libitum diet $(3.7 \pm 0.8 \mu \mathrm{g}$ $\mathrm{mg}^{-1}$ ) and the other two groups. Pituitary FSH content was not significantly different among groups $\left(0.20 \pm 0.04,0.38 \pm 0.11,0.25 \pm 0.15 \mu \mathrm{g} \mathrm{mg}^{-1}\right.$ for ewes offered the ad libitum, control and low diets, 
Table 2. Comparison between serum concentrations of insulin-like growth factor I (IGF-I; $\left.\mu \mathrm{g}\right|^{-1}$ ) before treatment and at day 13 after the start of nutritional treatment; and between serum concentrations of IGF-I ( $\mu \mathrm{g} \mathrm{I}^{-1}$ ) at days 1, 2, 3 and 4 after pessary withdrawal in superovulated ewes fed an ad libitum diet, or 1.5 (control) or 0.5 (low) times maintenance energy requirements

\begin{tabular}{|c|c|c|c|c|c|c|}
\hline \multirow[b]{2}{*}{ Treatment group } & \multicolumn{6}{|c|}{ IGF-I at } \\
\hline & $\begin{array}{l}\text { Start of } \\
\text { treatment }\end{array}$ & $\begin{array}{c}\text { Day } 13 \text { after } \\
\text { start of } \\
\text { treatment }\end{array}$ & $\begin{array}{l}\text { Day } 1 \text { after } \\
\text { pessary } \\
\text { withdrawal }\end{array}$ & $\begin{array}{l}\text { Day } 2 \text { after } \\
\text { pessary } \\
\text { withdrawal }\end{array}$ & $\begin{array}{l}\text { Day } 3 \text { after } \\
\text { pessary } \\
\text { withdrawal }\end{array}$ & $\begin{array}{l}\text { Day } 4 \text { after } \\
\text { pessary } \\
\text { withdrawal }\end{array}$ \\
\hline Ad libitum & $70.8 \pm 3.5$ & $76.0 \pm 3.8$ & $111.7 \pm 16.8$ & $104.5 \pm 13.7$ & $79.0 \pm 11.7$ & $67.6 \pm 7.2$ \\
\hline Control & $82.8 \pm 8.5$ & $92.4 \pm 12.2$ & $132.7 \pm 6.8$ & $122.0 \pm 30.2$ & $93.5 \pm 17.4$ & $76.6 \pm 16.7$ \\
\hline Low & $76.0 \pm 13.0$ & $95.0 \pm 12.7$ & $144.5 \pm 51.5$ & $83.2 \pm 15.8$ & $60.0 \pm 10.1$ & $54.8 \pm 11.2$ \\
\hline Mean & $76.5 \pm 5.1$ & $87.8 \pm 6.0$ & $127.8 \pm 12^{\mathrm{a}}$ & $103.1 \pm 12.7^{a}$ & $75.9 \pm 8.3^{b}$ & $66.3 \pm 7.6^{b}$ \\
\hline
\end{tabular}

Values are mean $\pm \mathrm{SE}$.

Low diet: diet of grass meal $\left(90 \%\right.$ dry matter (DM), $10.75 \mathrm{MJ}$ metabolizable energy $\mathrm{kg}^{-1} \mathrm{DM}, 16 \%$ crude protein in DM) calculated to provide 0.5 times the maintenance energy requirements; control diet: 1.5 times the maintenance energy requirements; ad libitum diet: intake estimated by residues $=2.2$ times the maintenance energy requirements.

ab Within rows, values with different superscripts are significantly different $(P<0.05)$.
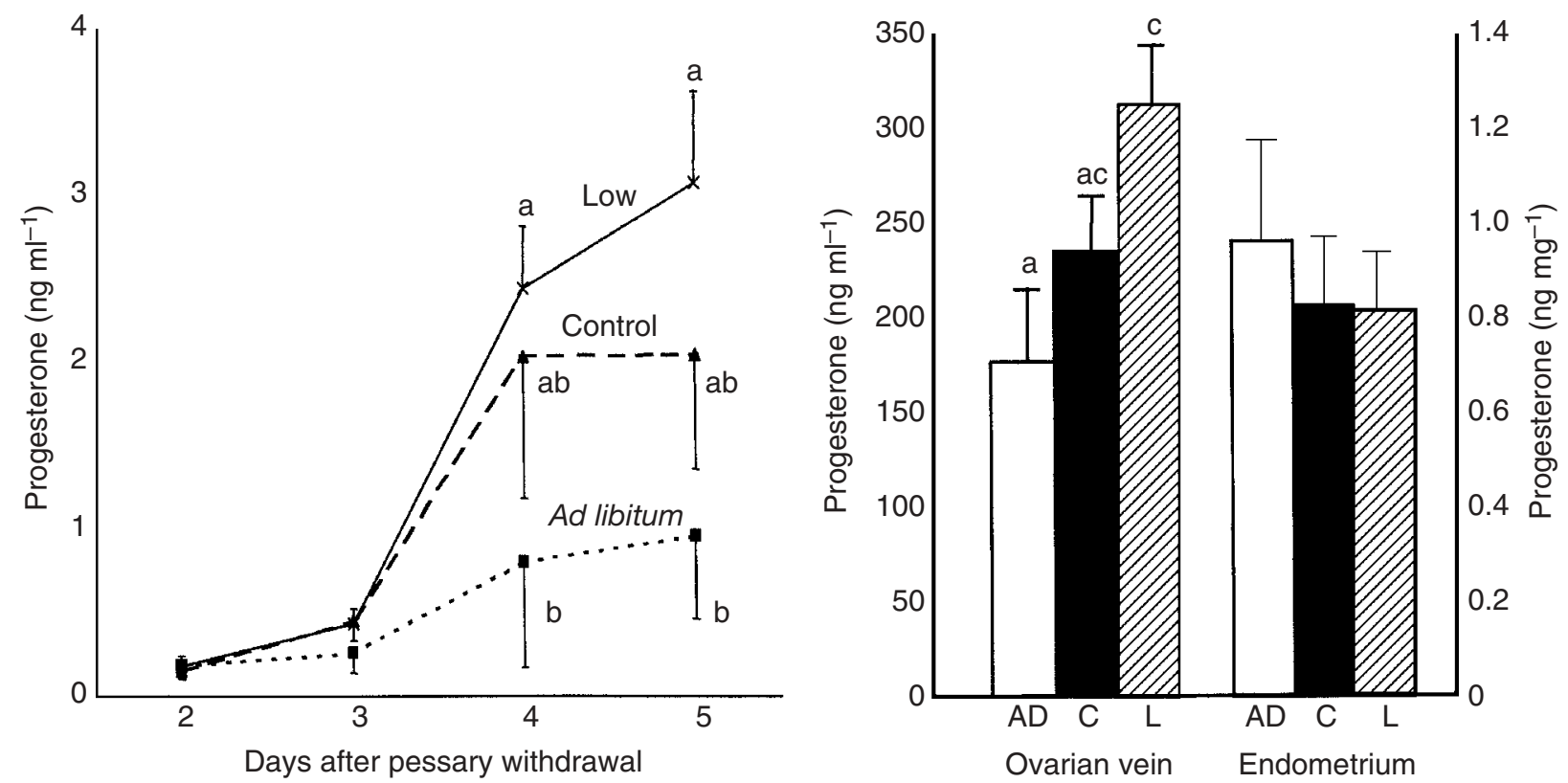

Fig. 2. (a) Change in the serum concentration of progesterone in the jugular vein on days 2-5 after pessary withdrawal and (b) serum concentrations of progesterone in the ovarian vein $\left(\mathrm{ng} \mathrm{ml}^{-1}\right)$ and endometrial progesterone content (ng $\left.\mathrm{mg}^{-1}\right)$ on the day the sheep were killed (day 4 and day 5) in synchronized, superovulated ewes fed an ad libitum diet (AD), 1.5 (C) or 0.5 (L) times maintenance energy requirements. ${ }^{\mathrm{a}, \mathrm{b}} \mathrm{P}<0.05 ;{ }^{\mathrm{a}, \mathrm{c}} P=0.07$. Low diet: diet of grass meal $(90 \%$ dry matter (DM), $10.75 \mathrm{MJ}$ metabolizable energy $\mathrm{kg}^{-1} \mathrm{DM}, 16 \%$ crude protein in DM) calculated to provide 0.5 times the maintenance energy requirements; control diet: 1.5 times the maintenance energy requirements; ad libitum diet: intake estimated by residues $=2.2$ times the maintenance energy requirements.

respectively). Pituitary content of FSH and ovulation rate tended to be positively correlated $(r=0.322, P=0.09)$.

Serum concentrations of IGF-I and insulin were not different among ewes in the different nutritional groups either at the start of the nutritional treatments or at 3 or 14 days later (Table 2). Serum concentrations of IGF-I increased during the periovulatory period, and there was a higher concentration at days 1 and 2 than at days 3 and 4 after ovulation $(P<0.05)$ (Table 2$)$.

Response to superovulation and synchronization. Sixtyfour per cent (7 of 11 ewes), 82\% (9 of 11) and 86\% (19 of 22) of the embryo donor ewes offered the ad libitum, control and low diets, respectively, showed oestrous 
behaviour. The percentage of ewes ovulating was lower $(P<0.05)$ in ewes offered the ad libitum diet $(45 \%, 5$ of 11) compared with ewes offered the control or low diets (73\%, 8 of $11 ; 86 \%, 19$ of 22 , respectively) $(P<0.05)$.

The interval from pessary withdrawal to onset of oestrus was longer in ewes offered the ad libitum diet $(44.6 \pm 5.9 \mathrm{~h})$ compared with ewes offered the control $(36 \pm 0$ h) or low diets $(36.6 \pm 2.8 \mathrm{~h})(P<0.05)$.

Ewes in the ad libitum dietary group tended to have a lower ovulation rate than ewes offered the control or low diets $(6.8 \pm 2.3,11.4 \pm 2.6$ and $11.4 \pm 1.6$ in ewes offered the ad libitum, control and low diets, respectively, $P=0.1$ ). Embryo recovery rate (embryos recovered divided by number of corpora lutea) was not different among groups $(79.4,80.2$ and $79.4 \%$ per ewes offered the ad libitum, control and low diets, respectively).

When all treated ewes were considered (including those that failed to ovulate), a trend for fewer embryos recovered per ewe on nutritional treatment was observed in ewes offered an ad libitum diet compared with ewes offered control or low diets $(2.5 \pm 1.2$ in the ewes offered the ad libitum diet, compared with $6.6 \pm 2.0$ and $7.1 \pm 1.4$ in the ewes offered control and low diets, respectively, $P=0.08$ ). Similarly, when all superovulated ewes were considered, the mean number of embryos with eight or more cells with acceptable morphology tended to be lower $(P=0.09)$ in ewes offered the ad libitum diet $(1.7 \pm 0.7)$, compared with ewes offered the control or low diets $(6.1 \pm 1.9$ and $5.8 \pm 1.5$ for ewes offered the control and low diets, respectively).

Embryo quality on day 4. Twelve animals (six ad libitum, three control and three low) that did not ovulate and five ewes offered the low diet that did not undergo surgery were removed from the experiment for the statistical analysis of embryo quality. Ewes fed the control diet had the highest percentage of good embryos $(92 \%$ of embryos morphologically acceptable and with eight or more cells) compared with 70 and $82 \%$ in the ad libitum and low diet groups, respectively $(P<0.05)$ (Table 3).

Ewes offered the low diet tended to have more unfertilized oocytes compared with ewes offered the control or ad libitum diets $(P=0.09)$. A delay in embryo development was observed in embryos recovered from ewes offered ad libitum diets (26\% of embryos recovered with fewer than eight cells) compared with 4 and $7 \%$ in ewes on the control and low diets, respectively $(P<0.05)$ (Table 3).

Embryo quality on day 16 . Only embryos with eight cells or more and acceptable morphology were transferred to recipients on day 4 of pregnancy. The diet of the embryo donor ewe did not modify any parameter in the embryos recovered 12 days later from the recipient (day 16 of pregnancy). Thus, no differences in recovery
Table 3. Ovulation rate (corpora lutea), number of embryos recovered and classification of these embryos at day 4 after mating in superovulated ewes fed an ad libitum diet, or 1.5 (control) or 0.5 (low) times the maintenance energy requirements

\begin{tabular}{lccc}
\hline & Ad libitum & Control & Low \\
\hline Treated ewes* $^{*}$ & 11 & 11 & 22 \\
Ewes responding & 5 & 8 & 14 \\
Corpora lutea & 34 & 91 & 160 \\
Embryos recovered & 27 & 73 & 127 \\
One-cell or empty & $1(0.04)^{\mathrm{a}}$ & $3(0.04)^{\mathrm{a}}$ & $14(0.11)^{\mathrm{c}}$ \\
$\quad$ zones & & & \\
Two- to eight-cells & $7(0.26)^{\mathrm{a}}$ & $3(0.04)^{\mathrm{b}}$ & $9(0.07)^{\mathrm{b}}$ \\
Eight-cells or more & $19(0.70)^{\mathrm{b}}$ & $67(0.92)^{\mathrm{a}}$ & $104(0.82)^{\mathrm{b}}$ \\
Eight-cells or more/ & 0.54 & 0.73 & 0.65 \\
$\quad$ corpora lutea & & & \\
\hline
\end{tabular}

Low diet: diet of grass meal (90\% dry matter (DM), $10.75 \mathrm{MJ}$ metabolizable energy $\mathrm{kg}^{-1} \mathrm{DM}, 16 \%$ crude protein in DM) calculated to provide 0.5 times the maintenance energy requirements; control diet: 1.5 times the maintenance energy requirements; ad libitum diet: intake estimated by residues = 2.2 times the maintenance energy requirements.

Values in parenthesis are the proportion with respect to the total number of embryos.

*Number of ewes undergoing superovulation.

$\dagger$ Number of ewes from which embryos were recovered.

Different superscripts indicate significant differences within rows ${ }^{\mathrm{a}, \mathrm{b}} P<0.05 ;{ }^{\mathrm{a}, \mathrm{c}} P=0.09$ ).

rate (embryos recovered/embryos transferred) or IFN- $\tau$ production in vitro were found in any of the groups (Table 4).

Neither the addition of oxytocin to the culture medium nor the presence of conceptus in the uterine horn modified the endometrial production of $\mathrm{PGF}_{2 \alpha}$ or $\mathrm{PGE}_{2}$ in vitro (Table 4). For subsequent statistical analysis, results from culture with and without oxytocin were pooled and only responses in uterine horns containing a conceptus were considered.

The diet of the embryo donor ewe did not modify production of $\mathrm{PGF}_{2 \alpha}$ and $\mathrm{PGE}_{2}$. The diet of the embryo recipient ewe modified production of $\mathrm{PGF}_{2 \alpha}$. Samples of endometrium collected from recipient ewes offered the low diet produced more $\mathrm{PGF}_{2 \alpha}$ after culture in vitro than did those collected from recipient ewes offered the control diet $(P<0.05)$. However, there was no difference in the production of $\mathrm{PGE}_{2}$ in vitro. Thus, the ratio of $\mathrm{PGF}_{2 \alpha}: \mathrm{PGE}_{2}$ was also higher in recipient ewes offered the low $\operatorname{diet}(P<0.05)$.

\section{Experiment 2}

Body weight and body condition score. There was no difference in initial body weight $(67.5 \pm 1.5$ and $68.6 \pm 1.9 \mathrm{~kg})$ or BCS $(2.58 \pm 0.08$ and $2.5 \pm 0.09)$ for ewes offered the ad libitum and low diets, respectively. After 3 weeks of nutritional treament, body weight was higher $(P<0.01)$ in ewes offered the ad libitum diet 
Table 4. Recovery rate of embryos transferred on day 4 and collected on day 16 of pregnancy from superovulated ewes fed an ad libitum diet, or 1.5 (control) or 0.5 (low) times maintenance energy requirements to recipients in low and control diets, and $\mathrm{PGF}_{2 \alpha}$ and $\mathrm{PGE}_{2}$ endometrial in vitro and IFN- $\tau$ embryonic in vitro secretion in uteri and embryos collected from recipients

\begin{tabular}{|c|c|c|c|c|c|}
\hline \multirow{2}{*}{$\begin{array}{l}\text { Recipient group } \\
\text { Donor group }\end{array}$} & \multicolumn{4}{|c|}{ Control } & \multirow{2}{*}{$\frac{\text { Low }}{\text { Low }}$} \\
\hline & Ad libitum & Control & Low & Total & \\
\hline Embryos transferred & 22 & 26 & 36 & 84 & 37 \\
\hline $\begin{array}{c}\text { Embryos recovered } \\
\text { (recovery rate) }\end{array}$ & $9(41)$ & $13(50)$ & $15(42)$ & $37(44)$ & $17(46)$ \\
\hline IFN- $\tau\left(\right.$ iu $\left.\mathrm{ml}^{-1} \times 10^{3}\right)$ & $25 \pm 13$ & $16 \pm 5$ & $27 \pm 12$ & $23 \pm 5.7$ & $9 \pm 5.1$ \\
\hline $\mathrm{PGF}_{2 \alpha}\left(\mathrm{ng} \mathrm{mg}^{-1}\right)$ & $1.00 \pm 0.32$ & $1.71 \pm 0.74$ & $0.92 \pm 0.24$ & $1.21 \pm 0.28^{\mathrm{a}}$ & $1.65 \pm 0.32^{b}$ \\
\hline $\mathrm{PGE}_{2}\left(\mathrm{ng} \mathrm{mg}^{-1}\right)$ & $0.26 \pm 0.06$ & $0.42 \pm 0.15$ & $0.31 \pm 0.05$ & $0.33 \pm 0.05$ & $0.43 \pm 0.09$ \\
\hline
\end{tabular}

Values are mean $\pm \mathrm{SE}$.

Low diet: diet of grass meal (90\% dry matter (DM), $10.75 \mathrm{MJ}$ metabolizable energy $\mathrm{kg}^{-1} \mathrm{DM}, 16 \%$ crude protein in DM) calculated to provide 0.5 times the maintenance energy requirements; control diet: 1.5 times the maintenance energy requirements; ad libitum diet: intake estimated by residues $=2.2$ times the maintenance energy requirements.

IFN- $\tau$ : interferon tau; $\mathrm{PGF}_{2 \alpha}$ : protstaglandin $\mathrm{F}_{2 \alpha} ; \mathrm{PGE}_{2}$; prostaglandin $\mathrm{E}_{2}$.

${ }^{\mathrm{ab}}$ Within rows, values with different superscripts are significantly different $(P<0.05)$.

Table 5. Oocytes recovered and oocytes classified as grade 1 per ewe (mean \pm SE), total oocytes cleaved/total oocytes cultured and blastocyts developed in day 7 of culture in oocytes collected from synchronized, superovulated ewes offered an ad libitum diet or 0.5 (low) times maintenance energy requirements

\begin{tabular}{lccc}
\hline & Ad libitum $(\%)$ & Low (\%) & Significance \\
\hline Number of ewes & 9 & 9 & \\
Total oocytes recovered per ewe & $5.8 \pm 1.1$ & $10.3 \pm 1.6$ & $P<0.05$ \\
Total grade 1 oocytes per ewe & $3.4 \pm 0.8$ & $7.6 \pm 1.4$ & $P<0.05$ \\
Grade 1 oocytes per total oocytes & $31 / 52$ & $68 / 93$ & $\mathrm{NS}$ \\
Oocytes cleaved per oocytes cultured & $18 / 52(34.6)$ & $43 / 84(51.1)$ & $P=0.09$ \\
Blastocysts developed per oocytes cultured & $14 / 52(26.9)$ & $24 / 84(28.6)$ & $\mathrm{NS}$ \\
Blastocysts developed per oocytes cleaved & $14 / 18(77.8)$ & $24 / 43(55.8)$ & $\mathrm{NS}$ \\
\hline
\end{tabular}

Low diet: diet of grass meal (90\% dry matter (DM), 10.75 MJ metabolizable energy kg-1 DM, 16\% crude protein in DM) calculated to provide 0.5 times the maintenance energy requirements; control diet: 1.5 times the maintenance energy requirements; ad libitum diet: intake estimated by residues $=2.2$ times the maintenance energy requirements.

Values in parenthesis are percentages.

NS: not significant.

$(68.7 \pm 1.2 \mathrm{~kg})$ compared with ewes offered the low diet $(60.9 \pm 1.8 \mathrm{~kg})$. BCS was also higher $(\mathrm{P}<0.05)$ in ewes offered the ad libitum diet (2.70 \pm 0.07$)$ compared with ewes offered the low diet $(2.33 \pm 0.13)$.

As in the first experiment, liver mass $(1.20 \pm 0.06$ and $0.77 \pm 0.05 \mathrm{~kg}$ for ewes offered the ad libitum and low diets, respectively, $P<0.05$ ) and the liver:body weight ratio $\left(1.7 \times 10^{-2} \pm 6.8 \times 10^{-4}\right.$ and $1.3 \times 10^{-2} \pm 6.1 \times 10^{-4}$, for ewes offered the ad libitum and low diets, respectively, $P<0.05$ ) were higher in the ewes offered the ad libitum diet than in those offered the low diet.

Oocyte collection and culture. Results of oocyte recovery and culture are shown (Table 5). More total oocytes and oocytes classified as grade 1 were recovered from animals offered the low diet than from those offered the ad libitum diet $(P<0.05)$. The cleavage rate (number of oocytes cleaved/total oocytes cultured) tended to be higher in the oocytes collected from ewes offered the low diet compared with those from ewes offered the ad libitum diet $(P=0.09)$ but the effect was not significant. Nutritional treatments did not modify blastocyst formation rate at day 5 or day 7 , when either total oocytes cultured or only oocytes that cleaved were considered.

\section{Discussion}

The experiments reported here show that short-term (up to 24 days) nutritional treatment modifies embryo quality, and that the effect is evident as early as day 4 of pregnancy. Moreover, results from the second experiment show an effect of nutrition on oocyte morphology and developmental capacity in vitro. In addition to effects on embryo quality, the results from the present study demonstrate that ad libitum diets are also detrimental 
for the superovulatory treatment as fewer ewes fed the ad libitum diet showed oestrous behaviour and ovulation rates were lower than in ewes fed the control or low diets.

The ad libitum diet clearly reduced the performance of the superovulatory treatment. In Expt 1, ewes offered the ad libitum diet had a lower ovulation rate than ewes offered the low or control diets and in Expt 2, fewer follicles and, thus, fewer oocytes were recovered from such ewes relative to those offered the low diet. Therefore, these results are similar to those of studies in superovulated beef heifers which also demonstrated a positive effect of low compared with high nutrition on production of large $(7-10 \mathrm{~mm}$ in diameter) follicles (Nolan et al., 1998) and ovulation rate (Yaakub et al., 1999). Moreover, an excess in energy supply decreased response to a superovulatory $\mathrm{FSH}$ treatment and embryo quality in Holstein dairy heifers (Humblot et al., 1997). However, other reports concluded that low nutrition intake was associated with a decrease in ovulation rate when compared with a control nutrition intake in synchronized non-superovulated ewes (Rhind et al., 1989). This outcome is most likely due to a lack of responsiveness of follicles in the last stages of folliculogenesis to gonadotrophins and, as a result, the degree of atresia increases. However, the gonadotrophic treatment associated with the superovulation in the current experiments may have maximized the individual potential of each ewe and overcome the negative effects of low energy intakes (McEvoy et al., 1995), resulting in no differences in ovulation rate between ewes offered low and control diets. A different experiment showed that more follicles ( $\geqslant 3 \mathrm{~mm}$ in diameter) were recovered in superovulated sheep offered 2.0 or $1.0 \times$ maintenance diet compared with those offered $0.5 \times$ maintenance diet. The differences with the present experiment could be due to variations in the diets and to the fact that the follicles were counted before the $\mathrm{LH}$ surge $\left(\mathrm{O}^{\prime}\right.$ Callaghan et al., 2000).

Probably the most relevant result in the present study was the detrimental effect of the ad libitum diet on the quality of embryos and oocytes recovered after superovulation. The percentage of normal embryos (eight-cells or more and acceptable morphological classification) collected from ewes fed the ad libitum diet was lower compared with those collected from ewes fed the control diet. This difference was due to a delay in development in a higher percentage of the embryos recovered from ewes offered the ad libitum diet than in those fed the control or low diets. The delay in the onset of oestrus and, thus, ovulation, could partially explain the delay in embryo development. However, in Expt 2, ad libitum intakes had a negative effect on the morphological classification and cleavage rate of oocytes. Previous experiments have shown a detrimental effect of high energy diets on the development in vitro of embryos recovered as early as day 2 of pregnancy (Creed et al., 1994). This finding indicates that the detrimental effect of high energy intakes on embryo development are exerted, at least partially, before fertilization, during the acquisition of oocyte developmental competence.

A lower percentage of good embryos was collected from ewes offered the low diet than from ewes fed the control diet. However, unlike the ad libitum group, fertilization failure and not a delay in embryo development seems to be the most common cause, as the number of empty zonae pellucidae and unfertilized oocytes recovered tended to be higher in ewes fed the low diet compared with those fed the control diet. Rhind et al. (1989) reported an increase in embryo mortality in ewes fed the low diet after mating compared with those fed the control diet, but no effect was found when the low diet was fed exclusively before mating. Thus, the authors suggested that the negative effect of low energy intakes on embryo development is exerted during the period of embryo development and not during the period of acquisition of oocyte developmental competence. The results from Expt 2 support this theory, as a greater percentage of oocytes obtained from ewes offered the low diet were classified as grade 1 and they had a higher cleavage rate compared with those collected from ewes offered the ad libitum diet.

Progesterone, the main hormone sustaining pregnancy, may play an important role in mediating the effect of nutrition on embryo development. The results from Expt 1 show an inverse relationship between energy intake and jugular progesterone concentration, confirming a result found in previous experiments in sheep (Parr et al., 1987; Rhind et al., 1989; Creed et al., 1994). The low concentrations of progesterone in ewes fed the ad libitum diet is likely to be due to fewer corpora lutea (Thorburn et al., 1969) and to a faster clearance rate of progesterone as result of a higher liver mass (Parr et al., 1993). However, jugular and endometrial concentrations of progesterone were not related at all and this result is in agreement with a report by Lozano et al. (1998). There is a countercurrent mechanism of transport of progesterone from the ovarian vein to the ovarian artery, before it enters general circulation (Hunter, 1987) so the concentration of progesterone in the uterine environment is several times higher than that in the peripheral circulation. These results highlight the need for examining the progesterone concentration in the local environment of the embryo (at the ovary and uterus) instead of peripherally (at the jugular vein) when studying embryo mortality.

Although diet can markedly affect insulin and related hormones, this experiment failed to demonstrate a role for IGF-I and insulin in the effect of nutrition on embryo development. Other studies have shown no effect of diet on plasma or follicular fluid concentrations of IGF-I (Spicer et al., 1991), although short-term fasting for $48 \mathrm{~h}$ decreased circulating IGF-I concentrations (Spicer et al., 1992). Differences with this experiment could be due to the time of collection of blood relative to the start of the nutritional treatment, as in the present 
experiment IGF-I was measured 13 days after the start of the nutritional treatment. However, even without a difference in systemic IGF-I, the bioavailability of IGF-I could be different as a result of different concentrations of IGF binding proteins (IGFBP). In steers, nutrition modifies serum concentrations of IGFBP 2, 3 and 4 (Lee et al., 2000). Thus, it is quite possible that nutrition regulates the bioavailability of IGF-I through the control of IGFBPs and a study of IGF-I concentration only is insufficient when analysing its role on the effect of nutrition on embryo or oocyte development.

When only good embryos were transferred on day 4 of pregnancy, the nutritional status of the embryo donor ewe did not modify the embryo quality 12 days later, on day 16 of pregnancy. It was concluded that, although nutrition influences early embryo development, good embryos transferred at the correct stage of development have the same likelihood to survive, regardless of the nutritional status of the embryo donor ewe. This effect has been observed before at an earlier stage of development, as oocytes obtained from ewes that were offered different diets had the same likelihood to survive once they cleaved, regardless of the nutritional treatment of the donor (Papadopoulos et al., 2001).

The nutritional status of the recipient ewe did not affect the quality of the embryo at day 16 of pregnancy, as measured by embryo recovery rate at day 16 and production of IFN- $\tau$ in vitro. However, the endometrial secretion of $\mathrm{PGF}_{2 \alpha}$ in vitro was higher when the cultured endometrium came from recipient ewes offered the low diet compared with ewes offered control diet. In goats, an increase in progesterone concentration immediately after ovulation shortens the duration of the luteal phase (Menchaca and Rubianes, 2001) and the authors suggest a negative effect of progesterone in luteotrophic support or a premature release of luteolysin. Thus, the increase in plasma progesterone secretion in ewes fed the low diet could lead to an increase in endometrial secretion of $\mathrm{PGF}_{2 \alpha}$ in vitro. This adverse uterine environment could be detrimental to the survival or the further development of the embryo, even during postnatal life. Thus, some experiments have shown a negative effect of undernutrition on fetal development (Borwick et al., 1997) and on offspring fertility (Gunn et al., 1995; Wallace et al., 1999).

In summary, the ad libitum diet has a highly detrimental effect on the performance of a superovulatory treatment when compared with both control and low diets, not only in the number of oocytes or embryos yielded, but also in the quality of the oocytes and day 4 embryos recovered. The superovulatory response of ewes offered the low diet was similar to that in ewes offered the control diet, but with a higher percentage of fertilization failures, probably as a result of postovulatory events.

Finally, although nutritional treatments had no effect on embryo survival or embryo production of IFN- $\tau$ in vitro at day 16 , the low diets induced a poorer uterine environment for embryo development as measured by the endometrial production of $\mathrm{PGF}_{2 \alpha}$ in vitro. This result confirms the effect of low energy intake on embryo quality through postovulatory events.

This study was funded by TMR Marie Curie Research Training Grant ERB4001GT975226. J. M Lozano was supported by this grant. The authors are thankful to J. Martal, N. Chene and R. L'Haridon at INRA, Station de Physiologie Animale, Jouy-enJosas Cedex, France for the analysis of IFN- $\tau$. The authors are also grateful to A. F. Parlow (NIDKK) for the donation of the LH and FSH antiserum.

\section{References}

Abecia JA, Rhind SM, Bramley TA and McMillen SM (1995) Steroid production and $\mathrm{LH}$ receptor concentrations of ovarian follicles and corpora lutea and associated rates of ova wastage in ewes given high and low levels of food intake before and after mating Animal Science $6157-62$

Abecia JA, Lozano JM, Forcada F and Zarazaga L (1997) Effect of level of dietary energy and protein on embryo survival and progesterone production on day eight of pregnancy in Rasa Aragonesa ewes Animal Reproduction Science 48 209-218

Asselin E, Bazer FW and Fortier MA (1997) Recombinant ovine and bovine interferon tau regulate prostaglandin production and oxytocin response in cultured bovine endometrial cells Biology of Reproduction $\mathbf{5 6}$ 402-408

Borwick SC, Rhind SM, McMillen SR and Racey PA (1997) Effect of undernutrition of ewes from the time of mating on fetal ovarian development in mid-gestation Reproduction, Fertility and Development $9711-715$

Carolan C, Lonergan P, Van Langendockt A and Mermillod P (1995) Factors affecting bovine embryo development in synthetic oviduct fluid following maturation and fertilization in vitro. Theriogenology 431115 1128

Creed J, McEvoy TG, Robinson JJ, Aitken RP, Palmer RM and Robertson I (1994) The effect of preovulatory nutrition on the subsequent development of superovulated sheep ova in an in vitro culture system Animal Production 58 Abstract 82

Crowe MA, Padmanabhan V, Hynes N, Sunderland SJ, Enright WJ, Beitnis IZ and Roche JF (1997) Validation of a sensitive radioimmunoassay to measure serum follicle-stimulating hormone in cattle: correlation with biological activity Animal Reproduction Science 48 123-136

Fahey J, Boland MP and O'Callaghan D (2001) The effects of dietary urea on embryo development in superovulated donor ewes and on early embryo survival and development in recipient ewes Animal Science 72 395-400

Gunn RG, Sim DA and Hunter EA (1995) Effects of nutrition in utero and in early-life on the subsequent lifetime reproductive-performance of Scottish Blackface ewes in two management-systems Animal Science $60223-230$

Humblot P, Negrao S, Marie M, Jeanguyot N and Nibart M (1997) Relationship between diet content, metabolic status and embryo production following superovulation in Prim Holstein dairy cattle Journal of Reproduction and Fertility Abstract Series 20 Abstract 60

Hunter RHF (1987) The Fallopian Tubes: Their Role in Fertility and Infertility p 47 Springer-Verlag, London

La Bonnardière C and Laude H (1981) High interferon titer in newborn pig intestine during experimentally induced viral enteritis Infection and Immunity 32 28-31

Lee HG, Vega RA, Phung LT, Matsunaga $N$, Kuwayama $H$ and Hidari H (2000) The effect of growth hormone-releasing peptide-2 (KP102) administration on plasma insulin-like growth factor (IGF)-I and IGF-binding proteins in Holstein steers on different planes of nutrition Domestic Animal Endocrinology 18 293-308 
Lozano JM, Abecia JA, Forcada F, Zarazaga L and Alfaro B (1998) Effect of undernutrition on the distribution of progesterone in the uterus of ewes during the luteal phase of the cycle Theriogenology 49 539-546

McEvoy TG, Robinson JJ, Aitken RP, Findlay PA, Palmer RM and Robertson IS (1995) Dietary induced suppression of preovulatory progesterone concentrations in superovulated ewes impairs the subsequent in vivo and in vitro development of their ova Animal Reproduction Science 39 89-107

Martal J, Chêne N, Huynh L, L'Haridon RM, Reinaud PB, Guillomot MW, Charlier MA and Charpigny SU (1998) IFN-tau: a novel subtype I IFN1. Structural characteristics, non-ubiquitous expression, structure-function relationships, a pregnancy hormonal embryonic signal and cross-species therapeutic potentialities Biochimie 80 755-777

Menchaca A and Rubianes E (2001) Effect of high progesterone concentrations during the early luteal phase on the length of the ovulatory cycle of goats Animal Reproduction Science $\mathbf{6 8} 69-76$

Nolan R, O'Callaghan D, Duby RT, Lonergan P and Boland MP (1998) The influence of short-term nutrient changes on follicle growth and embryo production following superovulation in beef heifers Theriogenology $\mathbf{5 0}$ 1263-1274

O'Callaghan D, Yaakub H, Hyttel P, Spicer LJ and Boland MP (2000) Effect of nutrition and superovulation on oocyte morphology, follicular fluid composition and systemic hormone concentrations in ewes Journal of Reproduction and Fertility 118 303-313

Papadopoulos S, Lonergan P, Gath V, Quinn KM, Evans ACO, O'Callaghan D and Boland MP (2001) Effect of diet quantity and urea supplementation on oocyte and embryo quality in sheep Theriogenology 55 10591069

Parr RA, Davis IF, Fairclough RJ and Miles MA (1987) Overfeeding during early pregnancy reduces peripheral progesterone concentration and pregnancy rate in sheep Journal of Reproduction and Fertility $\mathbf{8 0} 317-$ 320

Parr RA, Davis IF, Miles MA and Squires TJ (1993) Feed intake affects metabolic clearance rate of progesterone in sheep Research in Veterinary Science 55 306-310

Rhind SM, McKelvey WAC, McMillen SR, Gunn RG and Elston DA (1989) Effect of restricted food intake, before and/or after mating, on the reproductive performance of Greyface ewes Animal Production 48 149-155
Spencer TE and Bazer FW (1996) Ovine interferon tau suppresses transcription of the estrogen receptor and oxytocin receptor genes in the ovine endometrium Endocrinology 137 1144-1147

Spicer LJ and Zavy MT (1992) Concentrations of insulin-like growth factor I in serum of sheep with different ovulation rates changes during the estrous cycle Theriogenology 37 395-405

Spicer LJ, Enright WJ, Murphy MG and Roche JF (1991) Effect of dietary, intake on concentrations of insulin-like growth factor I in plasma and follicular fluid, and ovarian function in heifers Domestic Animal Endocrinology 8 431-437

Sweeney T, Donovan A, Roche JF and O'Callaghan D (1997) Variation in the ability of a long day followed by a short day photoperiod signal to initiate reproductive activity in ewes at different times of the year Journal of Reproduction and Fertility 109 121-127

Thibodeaux JK, Broussard JR, Godke RA and Hansel W (1994) Stimulation of progesterone production in bovine luteal cells by co-incubation with bovine blastocyst-stage embryos or trophoblastic vesicles Journal of Reproduction and Fertility 101 657-662

Thorburn GD, Basset JM and Smith ID (1969) Progesterone concentration in the peripheral plasma of sheep during the oestrus cycle Journal of Endocrinology 45 459-469

Wallace JM, Bourke DA and Aitken RP (1999) Nutrition and fetal growth: paradoxical effects in the overnourished adolescent sheep Journal of Reproduction and Fertility Supplement 54 385-399

Ward FA, Lonergan P, Enright BP and Boland MP (2000) Factors affecting recovery and quality of oocytes for bovine embryo production in vitro using ovum pick-up technology Theriogenology 54433 446

Yaakub H, O'Callaghan D and Boland MP (1999) Effect of type and quantity of concentrates on superovulation and embryo yield in beef heifers Theriogenology 51 1259-1266

Received 6 June 2002.

First decision 12 July 2002.

Revised manuscript received 18 December 2002.

Accepted 13 January 2003. 